\title{
Analisis Mutu Proses Produksi Kertas Dupleks dengan Mempertimbangkan Waktu Kerusakan untuk Meminimumkan Biaya Cacat
}

\author{
Asti Widayanti ${ }^{1}$ dan Ike Rostika ${ }^{2}$ \\ ${ }^{1}$ D3 Sistem Informasi Akuntansi, Universitas Telkom, Jl. Telekomunikasi No.1 Bandung \\ ${ }^{2}$ Balai Besar Pulp dan Kertas, Jl. Raya Dayeuhkolot No.132 Bandung
}

Diterima : 29 Oktober 2019, Revisi akhir : 23 Desember 2019, Disetujui terbit : 30 Desember 2019

\author{
Analysis Quality of Production Process Duplex Paper by Considering Failure Time to \\ Minimize Failure Cost
}

\begin{abstract}
This research analyzing the quality of the PT. X duplex paper production process and determine the optimum maintenance time that can minimize failure cost, through identification of the dominant production process that causes defects by using the Statistical Process Control (SPC). Coating process are the most dominant stages in the occurrence of defects in the duplex paper machine 3, which resulted in a loss for the company of 32.96\% or Rp893,140,000.00. Defects in the coating process are caused by material, machine, operator and test measurements, with machine factor as the largest contributor by $81.50 \%$. The time between failure in the coating process have non-homogeneous posson process, power law model with a mean time of 4 hours. The optimum preventative maintenance time for a coating machine is after a 199.32 hour operation with a risk of Rp13,719,929.00. This cost risk is Rp602,983,033.00 a year or reduce the defects cost in the coating process by Rp290,156,967.00.
\end{abstract}

Keywords: duplex, statistical process control, defect, time between failure, cost

\begin{abstract}
Abstrak
Penelitian ini menganalisis kualitas proses produksi kertas dupleks yang diproduksi PT.X paper mill dan menentukan waktu pemeliharaan optimum yang meminimumkan biaya cacat, dengan identifikasi proses produksi dominan penyebab cacat menggunakan Statistical Process Control (SPC). Tahapan yang paling dominan dalam terjadinya cacat pada proses produksi kertas dupleks paper machine 3 adalah proses coating yang mengakibatkan kerugian bagi perusahaan sebesar 32,96\% atau Rp893.140.000,00. Cacat pada proses coating disebabkan faktor bahan, mesin, operator dan pengukuran pengujian, dengan faktor mesin berkontribusi terbesar yaitu $81,50 \%$. Waktu antar kerusakan pada proses coating memiliki model proses posson non homogen model power law dengan rata-rata 4 jam. Waktu pemeliharaan pencegahan optimum mesin coating adalah setelah mesin beroperasi 199,32 jam dengan resiko biaya Rp13.719.929,00. Resiko biaya ini senilai Rp602.983.033,00 setahun atau mengurangi biaya cacat pada proses coating Rp290.156.967,00.
\end{abstract}

Kata kunci: dupleks, statistical process control, cacat, waktu antar kerusakan, biaya 


\section{Pendahuluan}

Indonesia merupakan negara peringkat ke 6 untuk produsen kertas terbesar di dunia, yang mana memiliki 82 industri pulp dan kertas dengan kapasitas produksi dapat mencapai 18,96 juta ton (http://www.kemenperin.go.id, 2017). Produksi kertas tersebut digunakan baik untuk memenuhi kebutuhan dalam negeri maupun kebutuhan ekspor. Kebutuhan kertas dalam negeri Indonesia saat ini mencapai $26 \mathrm{~kg}$ per kapita per tahun atau 5,60 juta ton per tahun. Persaingan di antara industri kertas semakin ketat. Disamping itu, biaya produksi kertas pun mengalami peningkatan yang cukup tinggi. PT. X paper mill merupakan salah satu pabrik kertas di Indonesia dengan salah satu mesin yaitu Paper Machine 3 (PM-3) memproduksi dupleks paper coating dengan kapasitas produksi 120-150 ton/hari dan kecepatan maksimum operasi $150 \mathrm{~m} /$ menit. Duplex paper coating merupakan jenis karton bersalut (coating) yang terdiri atas tiga lapisan. Berdasarkan dua jenis inspeksi yang dilakukan oleh Divisi Finishing and Finished Good dan Divisi Quality Assurance meliputi inspeksi laboratorium dan inspeksi visual (dilakukan secara manual) diketahui bahwa dalam beberapa tahun terakhir cacat produksi kertas dupleks PM-3 yang terjadi rata-rata mencapai $10,7 \%$. yaitu tahun 2017 sebesar $10,3 \%$ dan tahun 2018 sebesar $11,13 \%$.

Metode Statistical Process Control (SPC) adalah salah satu metode yang sering digunakan untuk mencari penyebab-penyebab cacat dan potensi kerusakan terbanyak, metode ini telah digunakan di beberapa penelitian untuk identifikasi proses utama terjadinya cacat. Beberapa penelitian sebelumnya tentang metode SPC antara lain dilakukan oleh Ilham (2012) menggunakan SPC untuk mencari penyebabpenyebab kerusakan produk cacat di industri percetakan, tingkat kerusakan yang paling tinggi adalah tinta kabur dengan jumlah kerusakan mencapai 57.555 eksemplar dari 73.789 eksemplar produk yang rusak. Rekomendasi tindakan perbaikan pada penelitian ini diantaranya pemeliharaan mesin secara rutin. Kaban (2016) menggunakan SPC untuk mengidentifikasi cacat produksi plastik pouch kemasan, dalam penelitian diketahui bahwa proses pengendalian kualitas perusahaan kurang baik dikarenakan performansi kualitas produksi bulanan yang seringkali diluar batas kontrol kendali, saran yang diberikan dalam penelitian ini adalah melakukan maintenance rutin. Sidartawan (2014) menggunakan SPC untuk pengendalian kualitas di produksi snack yang menunjukkan bahwa kualitas proses produksi belum terkendali, kecacatan terbanyak terjadi karena mesin yang kurang baik dengan rasio kemampuan proses mencapai 0.2 sehingga tindakan perbaikan perlu dilakukan. Wicaksana (2017) menggunakan SPC untuk pengendalian kualitas di produksi semen, dalam penelitian ini diketahui bahwa tingkat cacat yang terjadi adalah $1,19 \%$, faktor penyebab terjadinya cacat adalah faktor material, faktor lingkungan, faktor manusia dan faktor mesin, untuk menanggulangi cacat pada mesin di antaranya dengan melakukan penjadwalan pemeliharaan mesin secara rutin. SPC telah digunakan untuk pengendalian kualitas di produksi Jenang (Faiq, Hajati and Hufron, 2018).

Penggunaan SPC untuk pengendalian kualitas di produksi kertas telah dilakukan pada pengendalian mutu produksi kertas karton, dengan jenis kecacatan terbanyak (80\%) yaitu tingkat smoothness permukaan dan hasil peta kendali yang menunjukan bahwa proses belum terkendali (Ihwah and Ekatama, 2019). Kecacatan terjadi karena pengaruh bahan, tenaga kerja, lingkungan dan mesin, pengecekan lebih rutin dan teliti terhadap seluruh bagian mesin menjadi rekomendasi dalam penelitian ini. Pengendalian kualitas menggunakan SPC untuk mempertimbangkan tipe dan penyebab cacat yang paling sering ditemukan di produksi kertas gelombang, dalam penelitian ini dianalisis faktor-faktor penyebab cacat. Hasil analisis menunjukkan bahwa kecacatan produk terbanyak yaitu kecacatan wavy dengan persentase $81,7 \%$, faktor penyebab utama kecacatan wavy karena tindakan pemeliharaan yang tidak terjadwal dengan baik, dengan proses pemeliharaan dilakukan hanya jika terjadi kerusakan mesin (Devani and Wahyuni, 2017).

Hasil penelitian dengan pendekatan SPC, diketahui bahwa faktor utama penyebab cacat adalah karena mesin yaitu waktu pemeliharaan yang tidak terjadwal dengan baik, perusahaan tidak mempertimbangkan waktu antar kerusakan sebagai dasar untuk melakukan penjadwalan proses perbaikan. Pengaruh tindakan pencegahan dan perbaikan terhadap rata-rata waktu antar kerusakan atau waktu terjadinya cacat dengan menggunakan studi kasus di PT. Riau Andalan Pulp and Paper, dari hasil penelitian ini diketahui 
bahwa tindakan pemeliharaan memiliki pengaruh yang signifikan terhadap waktu antar kerusakan (Daulay, Nurutami and Daniel, 2013). Besarnya pengaruh yang diberikan tindakan pemeliharaan terhadap rata-rata waktu antar kerusakan yaitu $50,3 \%$. Narayan (2012) menyatakan bahwa pemeliharaan menjadi salah satu faktor untuk meningkatkan profitability perusahaan. Penelitian dilkaukan untuk mengetahui hubungan antara keamanan, kualitas, keandalan produktivitas dan pemeliharaan. Kegiatan pemeliharaan memiliki hubungan signifikan dalam penurunan biaya karena dapat mengendalikan peluang terjadinya cacat. Penelitian tentang pemeliharaan, dan optimisasi biaya pemeliharaan dan pengendalian cacat telah menjadi topik penelitian yang masih berkembang saat ini (Starr et al., 2010). Pemeliharaan menjadi pendekatan untuk mengoptimalkan performansi dengan perkembangan awal yang berfokus kepada biaya berubah menjadi penentuan keuntungan.

PT. X paper mill biasanya melakukan tindakan pemeliharaan mesin PM-3 baik bersifat preventive (pencegahan) maupun corrective (perbaikan). Rata-rata waktu yang dibutuhkan untuk perbaikan apabila ada produk cacat adalah 5 menit (jenis perbaikan berupa setting ulang, atau pembersihan mesin). Rata-rata terjadinya cacat per hari adalah 20 kali sehingga waktu yang dibutuhkan untuk tindakan perbaikan adalah 1,67 jam/hari. Adapun tindakan pencegahan dilakukan terjadwal seminggu sekali dengan waktu downtime mesin sekitar 21,83 jam. Proses perbaikan dan pencegahan yang dilakukan tidak mempertimbangkan rata-rata produk cacat dan waktu antar kerusakan. Pada penelitian ini dilakukan analisis kualitas proses produksi kertas dupleks dan menentukan waktu pemeliharaan optimum yang dapat meminimumkan biaya kerusakan. Proses produksi yang memberikan kontribusi terbesar terjadinya cacat pada kertas dupleks diidentifikasi dengan menggunakan SPC. Pengendalian proses yang memberikan kontribusi terbesar terjadinya cacat diharapkan dapat mengurangi terjadinya cacat cukup signifikan atau mencapai kurang dari atau sama dengan 5\%. Pada tahap yang telah teridentifikasi dapat dianalisis waktu antar kerusakan (waktu terjadinya cacat) sehingga dapat diketahui waktu pemeliharaan mesin yang paling optimal dan dapat meminimumkan risiko biaya pemeliharaan.

\section{Bahan dan Metode}

\section{Alur Proses Mesin PM-3}

Bahan kertas dupleks terdiri dari lapisan atas terbuat dari pulp murni atau HVS. Lapisan tengah terbuat dari kertas bekas seperti kardus, karton, potongan kertas, atau broke (kertas hasil produksi yang mengalami cacat serius). Lapisan bawah terbuat dari kertas bekas yang lebih bersih dan halus daripada lapisan tengah. Kertas dupleks digunakan sebagai bahan kotak kemasan untuk berbagai jenis produk. Alur proses mesin untuk memproduksi kertas dupleks di PM-3 disajikan pada Gambar 1.

\section{Data Cacat, Data Biaya, Data Kerusakan}

Metode penelitian yang digunakan adalah metode kuantitatif dengan menggunakan data cacat, data antar kerusakan, dan data biaya. Data cacat yang digunakan adalah data yang berasal dari Divisi Quality Assurance PT. X paper mill. Jumlah dan jenis cacat produk

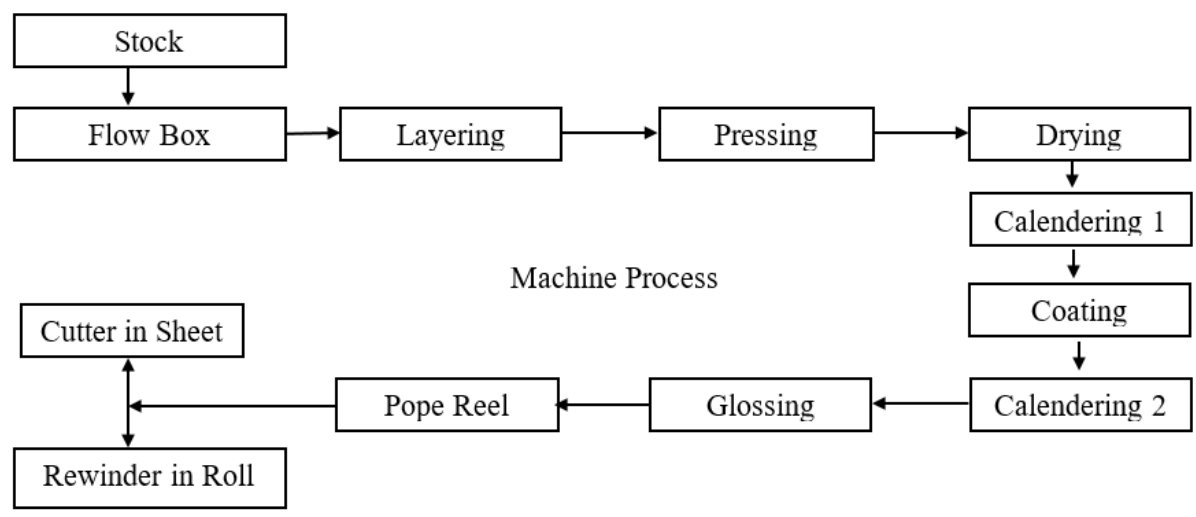

Gambar 1. Alur Proses Pembuatan Kertas Dupleks di PM-3 
kertas dupleks PM-3 untuk 3 bulan dengan total produksi adalah 12.841,81 ton. Karakteristik data ini dinamakan sifat (atribut) karena kualitas produk tidak dapat dengan mudah dinyatakan secara numerik, hanya diklasifikasikan sesuai pemenuhan terhadap spesifikasi karakteristik kualitas. PT. X paper mill mengklasifikasikan cacat dupleks menjadi tiga jenis yaitu cacat kelas B, C dan D. Cacat kelas B (serius) broke yaitu produk mengalami kecacatan serius dan dikembalikan sebagai bahan baku lapisan tengah, cacat kelas $\mathrm{C}$ (agak serius) - KW-3, produk mengalami kecacatan cukup serius tetapi masih dapat dipasarkan sebagai produk kualitas ketiga, dengan harga Rp7.000,00/kg, cacat kelas D (kecil) - KW-2, produk ini mengalami kecacatan kecil dan dipasarkan dengan harga Rp9.000,00/kg. Apabila diasumsikan harga penjualan produk kertas dupleks dianggap sama yaitu Rp11.000,00/kg maka kerugian yang dialami perusahaan untuk produk KW-2 adalah Rp2.000,00/kg, untuk produk KW-3 $\mathrm{Rp} 4.000,00 / \mathrm{kg}$ yang diasumsikan sebagai biaya cacat, dan untuk produk broke sebesar Rp11.000,00/kg. Dalam 2 tahun terakhir cacat produksi kertas dupleks PM-3 yang terjadi ratarata mencapai $10,7 \%$ yaitu tahun 2017 sebesar $10,3 \%$ dan tahun 2018 sebesar $11,13 \%$ sesuai dengan data laporan produksi pada Tabel 1.

Hal ini belum memperhitungkan kerugian untuk proses perbaikan, biaya produksi, biaya tenaga kerja dan lain-lain. Rekapitulasi banyaknya data cacat untuk setiap tahapan proses dan biaya cacat dapat dilihat di Tabel 2.

Data waktu antar kerusakan yang digunakan merupakan laporan harian, yang mencantumkan jenis cacat dan waktu cacat tersebut terjadi. Data yang digunakan sebanyak

Tabel 1. Laporan Produksi PM-3 PT. X Paper Mill (Data Laporan Produksi)

\begin{tabular}{lrrrrrr}
\hline Hasil Poduksi & \multicolumn{3}{c}{2017} & \multicolumn{3}{c}{2018} \\
\cline { 2 - 7 } & \multicolumn{1}{c}{$\begin{array}{c}\text { Jumlah } \\
\text { (ton) }\end{array}$} & $\begin{array}{c}\text { Cacat } \\
(\%)\end{array}$ & $\begin{array}{c}\text { Kerugian } \\
\text { (Rp000,00) }\end{array}$ & \multicolumn{1}{c}{$\begin{array}{c}\text { Jumlah } \\
\text { (ton) }\end{array}$} & $\begin{array}{c}\text { Cacat } \\
\text { (\%) }\end{array}$ & \multicolumn{1}{c}{$\begin{array}{c}\text { Kerugian } \\
\text { (Rp000,00) }\end{array}$} \\
\hline KW-1 & $40.700,99$ & & & $41.782,20$ & & \\
KW-2 & $2.618,94$ & 10,30 & 5.237 .880 & $3.165,40$ & 11,10 & 6.330 .800 \\
KW-3 & 667,16 & & 2.668 .640 & 811,00 & & 3.244 .000 \\
Total & $45.372,57$ & & 23.146 .800 & $47.017,11$ & & 23.418 .410 \\
\hline
\end{tabular}

Tabel 2. Jumlah Produk Cacat dan Biaya

\begin{tabular}{|c|c|c|c|c|c|c|c|c|}
\hline \multirow{3}{*}{$\begin{array}{l}\text { Tahapan } \\
\text { proses }\end{array}$} & \multicolumn{6}{|c|}{ Banyak Produk } & \multirow{2}{*}{\multicolumn{2}{|c|}{ Biaya Cacat }} \\
\hline & \multirow[b]{2}{*}{$\begin{array}{c}\mathrm{KW}-1 \\
\text { (ton) }\end{array}$} & \multicolumn{2}{|r|}{ KW-2 } & \multicolumn{2}{|c|}{ KW-3 } & \multirow[b]{2}{*}{$\begin{array}{c}\text { Kontribusi } \\
\text { Cacat } \\
(\%)\end{array}$} & & \\
\hline & & $\begin{array}{l}\text { Total } \\
\text { (ton) }\end{array}$ & $\begin{array}{c}\text { Biaya Cacat } \\
(\mathrm{Rp} 2000,00 / \mathrm{kg})\end{array}$ & $\begin{array}{l}\text { Total } \\
\text { (ton) }\end{array}$ & $\begin{array}{c}\text { Biaya Cacat } \\
(\mathrm{Rp} 2000,00 / \mathrm{kg})\end{array}$ & & $\begin{array}{l}\text { Total Biaya } \\
\quad(\mathrm{Rp})\end{array}$ & $\begin{array}{c}\% \\
\text { Biaya } \\
(\%)\end{array}$ \\
\hline $\begin{array}{l}\text { Stock } \\
\text { preparation }\end{array}$ & & 97,14 & 194.280 .000 & 75,13 & 300.520 .000 & 15,67 & 494.800 .000 & 17,97 \\
\hline Press & & 12,90 & 25.800 .000 & 43,73 & 174.920 .000 & 5,15 & 200.720 .000 & 7,29 \\
\hline Dryer & & 70,70 & 141.400 .000 & 15,89 & 63.560 .000 & 7,88 & 204.960 .000 & 7,45 \\
\hline Callender & & 24,91 & 49.820 .000 & 13,65 & 54.600 .000 & 3,51 & 104.420 .000 & 3,79 \\
\hline Coating & & 305,49 & 610.980 .000 & 70,54 & 282.160 .000 & 34,20 & 893.140 .000 & 32,44 \\
\hline Cutter \& Roll & & 167,23 & 334.460 .000 & 29,27 & 117.080 .000 & 17,87 & 451.540 .000 & 16,40 \\
\hline Waving & & 122,36 & 244.720 .000 & 28,47 & 113.880 .000 & 13,72 & 358.600 .000 & 13,03 \\
\hline Gloss & & 2,17 & 4.340 .000 & - & - & 0,20 & 4.340 .000 & 0,16 \\
\hline Bonding & & 19,48 & 38.960 .000 & 0,36 & 1.440 .000 & 1,80 & 40.400 .000 & 1,47 \\
\hline Total & $11.742,4$ & 822,38 & 1.644 .760 .000 & 277,04 & 1.108 .160 .000 & & 2.752 .920 .000 & \\
\hline$\%$ & $91,44 \%$ & $6,40 \%$ & & $2,16 \%$ & & & & \\
\hline $\begin{array}{l}\text { Total produksi } \\
\text { PM-3 }\end{array}$ & & & & & $12.841,81$ & & & \\
\hline
\end{tabular}


20 kerusakan dengan sampling tidak sinkron (asynchronously sampling) artinya sampel yang diambil berasal dari pengamatan yang dimulai pada suatu waktu tertentu namun awal kejadian tidak diketahui. Pengujian dihentikan setelah 20 kali kerusakan. Paper Machine 3 dapat memproduksi $3.754,58 \mathrm{~kg}$ per jam. Peluang pendapatan yang bisa diperoleh perusahaan Rp 41.300.380,00/jam (hasil kali rata-rata produksi per jam dengan harga produk $/ \mathrm{kg}$ Rp11.000,00/kg). Untuk menentukan biaya pemeliharaan dianalogikan dengan harga produk per $\mathrm{kg}$ dengan waktu yang diperlukan dalam melakukan pemeliharaan baik yang bersifat preventive (pencegahan) maupun corrective (perbaikan) dikalikan ratarata peluang pendapatan per jam. Dari data perusahaan sebelum waktu yang dibutuhkan untuk tindakan perbaikan (berupa pembersihan atau settin ulang mesin) adalah 1.67 jam. Maka biaya perbaikan yang menjadi risiko perusahaan adalah, mencapai Rp68.971.635,00 dapat disebut pula biaya perbaikan $\left(\mathrm{C}_{1}\right)$. Tindakan pencegahan yang dilakukan oleh perusahaan adalah terjadwal selama 1 bulan sekali membutuhkan downtime mesin sekitar 21,83 jam atau senilai Rp901.587.295,00 atau disebut pula biaya pemeliharaan pencegahan $\left(\mathrm{C}_{2}\right)$.

\section{Tahapan Penelitian}

Tahapan penelitian disajikan dalam Gambar 2 terdiri dari identifikasi penyebab terjadi cacat pada produksi kertas dupleks PM-3 dengan menggunakan alat bantu statistik yaitu diagram

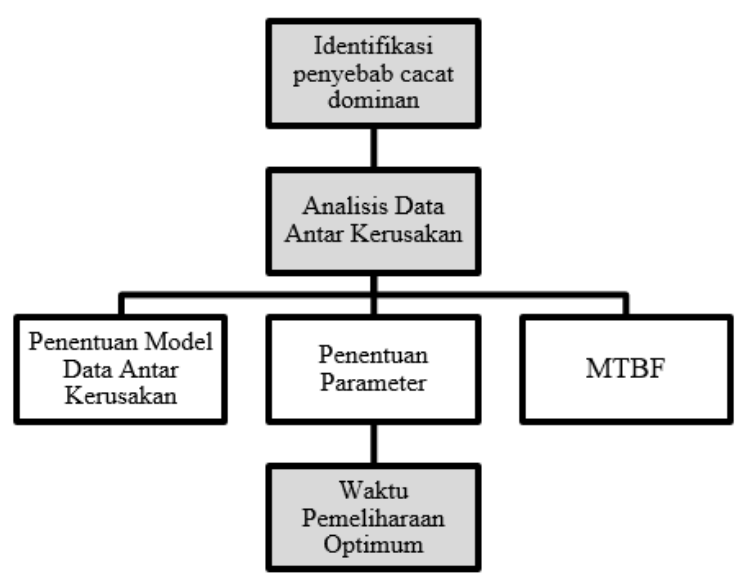

Gambar 2. Tahapan Penelitian histogram, fish bone dan pareto. Data yang digunakan untuk proses identifikasi ini adalah data cacat dan biaya. Tahap selanjutnya adalah analisis data antar kerusakan diawali dengan identifikasi model waktu antar kerusakan, penaksiran parameter penentuan rata-rata antar kerusakan. Data waktu antar kerusakan pada umumnya terdistribusi eksponensial atau Weibull. Langkah terakhir adalah penentuan waktu pemeliharaan optimum dan penentuan total biaya pemeliharaan.

\section{Hasil dan Pembahasan}

\section{Identifikasi Penyebab Cacat}

Dengan menggunakan data cacat dan biaya pada Tabel 2 proses identifikasi penyebab cacat yang digunakan adalah Statistical Process Control (SPC). SPC telah menjadi metode yang utama digunakan sebagai alat pengendalian kualitas untuk mengidentifikasi penyebab kecacatan pada produksi (Madanhire and Mbohwa, 2016). Pada gold practice terdapat 7 alat SPC dan kegunaannya yaitu check sheet (untuk menghitung terjadinya cacat), histogram (untuk mengidentifikasi kecenderungan data berpusat), diagram pareto (untuk mengidentifikasi 20\% dari faktor yang menghasilkan $80 \%$ masalah), diagram sebab akibat (untuk mengidentifikasi penyebab masalah), scatter diagram (untuk mengidentifikasi korelasi antar masalah), diagram kendali (untuk mengidentifikasi proses yang diluar kendali) dan grafik (untuk gambaran data) (Madanhire and Mbohwa, 2016). Pareto adalah metode untuk mengorganisasikan cacat dalam membantu fokus penyelesaian. Diagram Pareto dapat menghasilkan indikasi masalah terbesar (Render and Heizer, 2015). Data cacat dan biaya pada Tabel 2 menunjukkan bahwa dalam 3 bulan terakhir terdapat total cacat sebesar $8.56 \%$. Nilai ini lebih besar dari standar yang ditetapkan perusahaan yaitu 5\%. Identifikasi penyebab cacat terbesar dalam penelitian ini dengan menggunakan diagram histogram (Gambar 3) dan pareto (Gambar 4) sesuai data pada Tabel 2.

Diagram histogram digunakan untuk mengidentifikasi kecenderungan data berpusat. Gambar 3 menunjukkan kriteria cacat KW-2 dengan cacat terbanyak berasal dari proses coating yaitu 305,49 ton. Sedangkan untuk kriteria cacat KW-3, dengan cacat terbanyak berasal dari proses stock preparation yaitu 75,13 ton. Total 


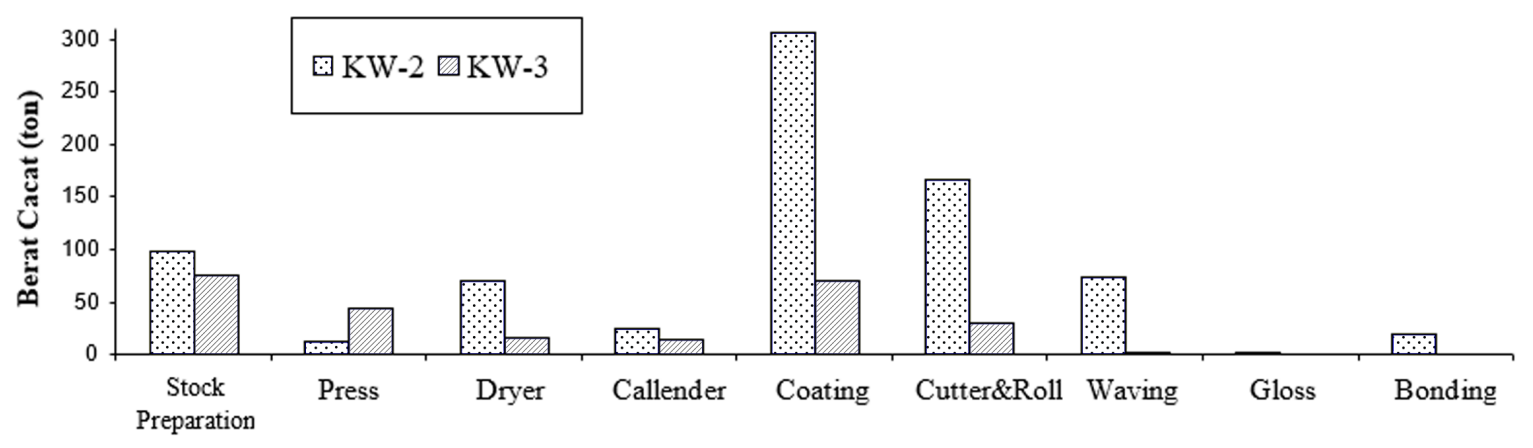

Tahapan Proses Produksi Paper Machine 3

Gambar 3. Histogram Produk Cacat PM-3

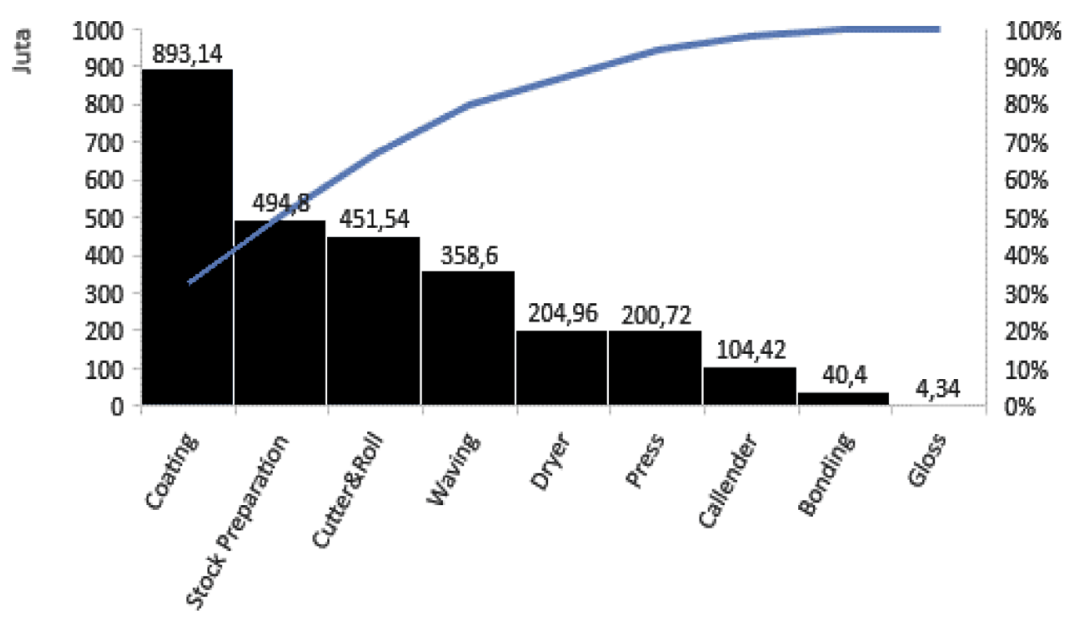

Gambar 4. Diagram Pareto Kerugian Akibat Cacat Kertas Dupleks PM-3

cacat terjadi pada Paper Machine 3 adalah $8 \%$ dengan cacat dari proses coating adalah 2,93\%. Dengan demikian, tindakan mengurangi cacat pada proses coating dapat mengurangi terjadinya cacat menjadi sekitar 5\%.

Diagram pareto (Gambar 4) menunjukkan unsur-unsur yang dapat dijadikan prioritas perusahaan untuk perbaikan. Berdasarkan Tabel 2 dapat disusun diagram pareto untuk total kerugian dari tiap-tiap proses produksi. Berdasarkan diagram pareto pada Gambar 4, terlihat bahwa tahapan proses produksi yang perlu diprioritaskan untuk dianalisis lebih lanjut adalah adalah tahapan coating, sesuai dengan prinsip pareto bahwa $20 \%$ dari cacat sistem dapat menyebabkan $80 \%$ masalah (Ihwah and Ekatama, 2019). Proses coating memberikan kontribusi total cacat secara jumlah
$34,20 \%$ dan mengakibatkan kerugian sebesar Rp893.140.000,00 atau $32,44 \%$ dari total kerugian pada proses produksi PM-3. Sehingga mengurangi atau meniadakan cacat pada proses coating dapat mengurangi cacat baik total maupun biaya sekitar $30 \%$.

Diagram sebab akibat merupakan diagram yang menunjukkan secara sistematis hubungan antara sebab dan akibatnya atau tujuan dengan caranya (Render and Heizer, 2015). Faktor penyebab terjadinya cacat pada proses coating dianalisis dengan menggunakan diagram sebab akibat yang disajikan dalam Gambar 5.

Pada diagram sebab akibat yang disajikan dalam Gambar 5, dapat terlihat bahwa cacat pada proses coating disebabkan oleh bahan yaitu campuran coating tidak tepat atau sifat dan komposisi bahan kimia yang bereaksi 


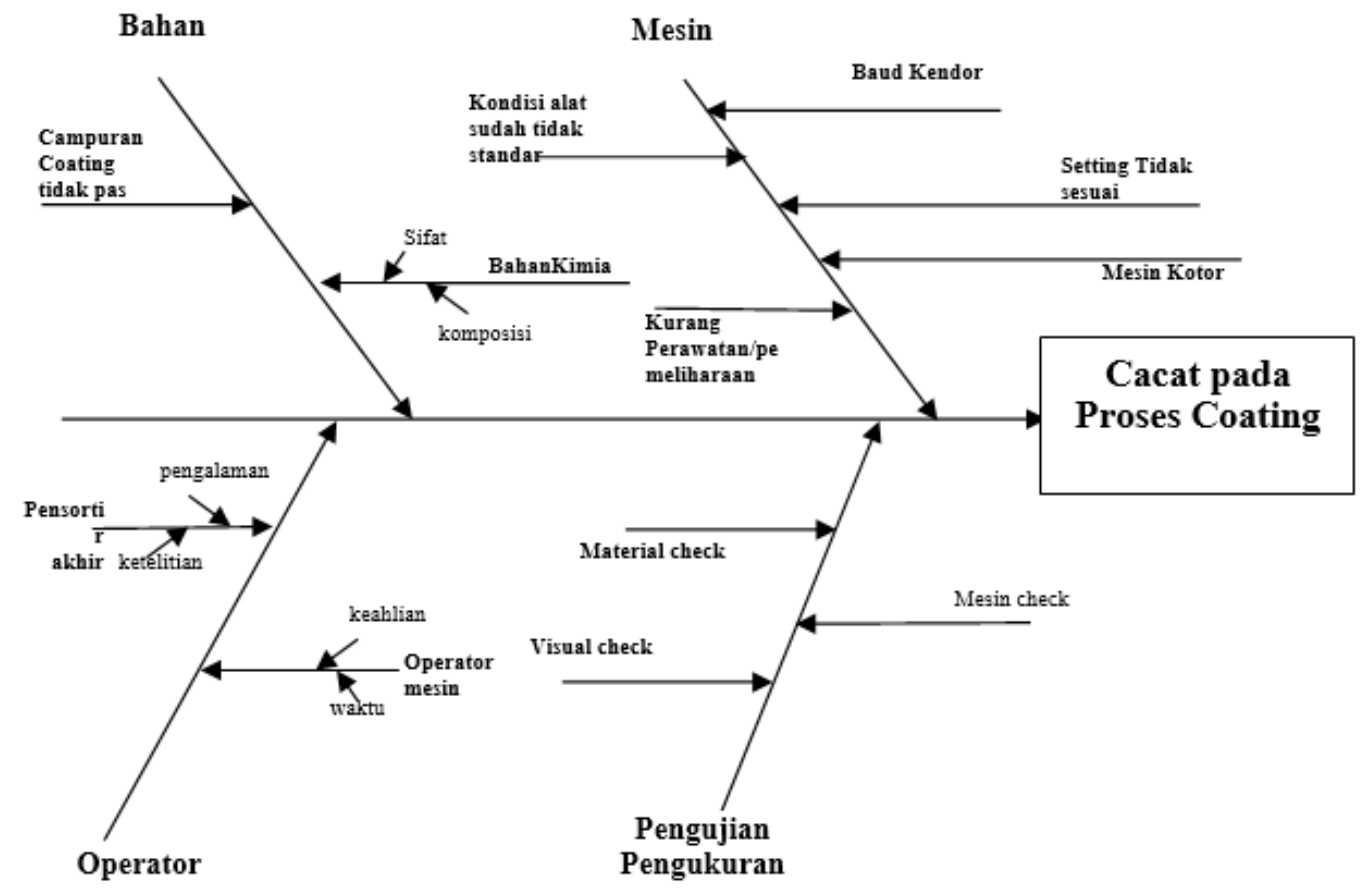

Gambar 5. Diagram Sebab Akibat Proses Coating

Tabel 3. Jenis, Total, Biaya dan Faktor Penyebab Cacat pada Proses Coating

\begin{tabular}{|c|c|c|c|c|c|c|}
\hline \multirow[b]{2}{*}{ Jenis Cacat } & \multicolumn{2}{|r|}{ KW-2 } & \multicolumn{2}{|r|}{ KW-3 } & \multirow{2}{*}{$\begin{array}{c}\text { Total Biaya } \\
\text { Cacat } \\
\text { (Rp) }\end{array}$} & \multirow{2}{*}{$\begin{array}{c}\text { Faktor } \\
\text { Penyebab } \\
\text { Utama }\end{array}$} \\
\hline & $\begin{array}{l}\text { Total } \\
\text { (ton) }\end{array}$ & $\begin{array}{c}\text { Biaya Cacat } \\
(\mathrm{Rp} 2000,00 / \mathrm{kg})\end{array}$ & $\begin{array}{l}\text { Total } \\
\text { (ton) }\end{array}$ & $\begin{array}{c}\text { Biaya Cacat } \\
(\mathrm{Rp} 4000,00 / \mathrm{kg})\end{array}$ & & \\
\hline Cacat coating & 146,06 & 292.120 .000 & 9,27 & 37.080 .000 & 329.200 .000 & Mesin \\
\hline Coating tidak rata & 51,25 & 102.500 .000 & 23,61 & 94.440 .000 & 196.940 .000 & Mesin \\
\hline Non coat & - & - & 28,77 & 115.080 .000 & 115.080 .000 & Bahan \\
\hline Garis coating & 50,60 & 101.200 .000 & 7,79 & 31.160 .000 & 132.360 .000 & Mesin \\
\hline Garis bercoat & 1,78 & 3.560 .000 & - & - & 3.560 .000 & Mesin \\
\hline Coating single & 21,99 & 43.980 .000 & 0,86 & 3.440 .000 & 47.420 .000 & Operator \\
\hline Semi coat bolong & 23 & 46.000 .000 & - & - & 46.000 .000 & Bahan \\
\hline Semi coat slime & 9,92 & 19.840 .000 & - & - & 19.840 .000 & Bahan \\
\hline $\begin{array}{l}\text { Coating kurang } \\
\text { pinggir }\end{array}$ & 0,72 & 1.440 .000 & 0,24 & 960.000 & 2.400 .000 & Pengujian \\
\hline Busa coating & 0,17 & 340.000 & - & - & 340.000 & Bahan \\
\hline Total & 305,49 & 610.980 .000 & 70,54 & 282.160 .000 & 893.140 .000 & \\
\hline
\end{tabular}

terhadap proses. Cacat karena faktor mesin dapat disebabkan oleh baud yang kendor, pengaturan yang tidak sesuai, kotor, kurang pemeliharaan atau kondisi alat yang sudah tidak standar. Cacat karena faktor operator antara lain keahlian, ketelitian, dan pengalaman operator dalam pensortiran akhir, dan operator mesin. Cacat pada pengujian dan pengukuran dapat disebabkan oleh material check, visual check, dan mesin check.
Detail jenis cacat pada proses coating dan faktor penyebab utama disajikan dalam Tabel 3. Tabel 3 menunjukkan bahwa mesin memiliki kontribusi utama terhadap faktor terjadinya cacat dengan total biaya kontribusi yaitu Rp727.900.000,00 atau sekitar $81,50 \%$ faktor penyebab utama proses coating dikarenakan mesin. Apabila pemeliharaan mesin dapat dikendalikan, maka cacat pada proses coating diharapkan dapat dikurangi. 


\section{Analisis Data Kerusakan}

Jika sebuah komponen memiliki tingkat kerusakan konstan $\lambda$ yang biasanya diperbaiki atau diganti setelah mengalami kerusakan. Banyaknya kerusakan setelah periode waktu t mengikuti distribusi Poisson. Proses poisson dibagi menjadi dua yaitu proses poisson homogen dan proses poisson non homogen (Aksioma, Haryono and Tyas, 2016)

\section{Proses Poisson Non Homogen}

Proses Poisson Nonhomogen (NHPP, Nonhomogeneous Poisson Process) merupakan sebuah fungsi poisson yang mempunyai nilai intensitas tidak konstan. Fungsi peluang kerusakan untuk model Power Law (Wolstenholme, 1999):

$P(N(T)=k)=\frac{\left(a t^{b}\right)^{k}}{k !} e^{-a t^{b}}$

Model Power Law cocok digunakan untuk menentukan nilai rata-rata total kerusakan waktu $t$ pertama, dengan rata-rata antar kerusakan Model ini seringkali disebut Proses Weibull. Tingkat kerusakan (ROCOF, nilai intensitas untuk model power law sesuai Persamaan (2) (Wolstenholme, 1999).

$$
\lambda(t)=a b t^{(b-1)}
$$

Untuk mengetahui bahwa model yang sesuai merupakan NHPP (Non Homogen Poisson Process) dengan model Power Law maka diuji dengan Military Hand Book Test (NIST/ SEMATECH, 2012). Misalkan terdapat n-1 kali kerusakan $\mathrm{T}_{1}, \mathrm{~T}_{2}, \ldots \mathrm{T}_{\mathrm{r}}$ dan pengamatan dihentikan pada waktu $T_{n}$ dengan $T_{n}>T_{r}$.

\section{Hipotesis Uji}

$\mathrm{H}_{0} \quad$ : NHPP Power Law merupakan model yang sesuai

$\mathrm{H}_{1} \quad$ : NHPP Power Law bukan merupakan model yang sesuai

\section{Statistik Uji}

Statistik uji yang digunakan untuk menguji adalah sesuai persamaan (3):

$$
\chi^{2}=2 \sum_{i=1}^{r} \ln \frac{T_{n}}{T_{i}}
$$

Dengan $\mathrm{n}$ adalah banyaknya kerusakan, $\mathrm{T}_{\mathrm{n}}$ adalah kumulatif total waktu antar kerusakan. Maka dari data antar kerusakan untuk pengamatan sebanyak 20 kali $(\mathrm{n}=20)$, diketahui $\mathrm{T}_{\mathrm{n}}=119$ sehingga sesuai persamaan (3) Diperoleh hasil $\chi_{\text {hitung }}^{2}=30,14$.

\section{Kriteria Uji}

Tolak $\mathrm{H}_{0}$ jika $\chi_{\text {hitung }}^{2}>\chi_{\text {tabel }(v=2(n-1)}^{2}$

Untuk $\alpha=0,05$ dan $\mathrm{n}=20$ maka $\mathrm{v}=38$ diproleh $\chi_{\text {tabel }(0,05 ; 38)}^{2}=55,8$ karena $\chi_{\text {hitung }}^{2}>\chi_{\text {tabel }(0,05 ; 38)}^{2}$ maka $\mathrm{H}_{0}$ diterima artinya NHPP power law merupakan model yang sesuai terhadap model kerusakan proses coating.

\section{Nilai Taksiran Parameter}

Nilai taksiran parameter dapat dihitung dengan menggunakan metode maksimum likelihood dimana fungsi densitas gabungan dari waktu kerusakan $\mathrm{T}_{1}, \mathrm{~T}_{2}, \ldots, \mathrm{T}_{\mathrm{n}}$ (Wolstenholme, 1999) adalah:

$$
f\left(t_{1}, t_{2}, \ldots, t_{n}\right)=\left(\prod_{i=1}^{n} \lambda\left(t_{i}\right)\right) \exp \left(-\int_{0}^{t_{n}} \lambda(x) d x\right)
$$

Dengan menggunakan metode maksimum likelihood persamaan (4) dan memasukkan tingkat kerusakan sesuai persamaan (2), taksiran parameter untuk data yang mengikuti model power law (Park and Pickering, 1997) adalah:

$\hat{a}=\frac{n}{t_{n}{ }^{b}}$

$$
\hat{b}=\frac{n}{\sum_{i=1}^{n-1} \ln \frac{t_{n}}{t_{i}}}
$$

Untuk model power law dengan menggunakan persamaan (5) dan persamaan (6) diperoleh $\hat{b}=$ 1,32699 dan $\hat{a}=0,03522$. 


\section{Penghitungan Intensitas}

Berdasarkan hasil taksiran sesuai persamaan 5 dan persamaan 6 maka nilai intensitas taksiran tingkat kerusakan pada mesin coating PM-3 PT. $\mathrm{X}$ paper mill sesuai persamaan adalah:

$\lambda(t)=0,04673 t^{0,32699}$

\section{Penghitungan MTBF (Mean Times Between Failure)}

MTBF adalah waktu rata-rata antar kerusakan atau rata-rata waktu beroperasi sub sistem tanpa mengalami kerusakan. Penentuan MTBF mengikuti persamaan 7 (Ebeling, 2004).

$$
M T B F=\int_{0}^{\infty} t f(t) d t
$$

dengan:

$\mathrm{t}=$ waktu rusak

$f(t)=$ fungsi waktu kerusakan

Fungsi peluang mengikuti persamaan (1). Nilai rata-rata waktu antar kerusakan (Persamaan 7) setelah mesin beroprasi selama 1 minggu yaitu sebanyak 168 jam operasi, waktu antar kerusakan pada tahap coating PM-3 adalah sebagai berikut:

$$
\begin{aligned}
\operatorname{MTBF}=\frac{1}{\lambda} & =\frac{1}{0,04674 t^{0,32699}} \\
& =\frac{1}{0,04674(168)^{0,32699}} \\
& =4,00
\end{aligned}
$$

Jadi, rata-rata waktu antar kerusakan setelah mesin beroperasi selama 1 minggu adalah sebesar 4,00 jam operasi.

\section{Menentukan Waktu Pemeliharaan Optimum}

Data waktu kerusakan mempunyai model Power Law, maka waktu pemeliharaan pencegahan optimal sesuai dengan Persamaan 8 (Ebeling, 2004).

$$
T=\left(\frac{C_{2}}{C_{1} a(b-1)}\right)^{\frac{1}{b}}
$$

dengan:

$\mathrm{C}_{1} \quad$ = biaya perbaikan

$\mathrm{C}_{2}$ = biaya pemeliharaan pencegahan (terjadwal)

Waktu pemeliharaan optimum mesin coating PM-3 jika diketahui bahwa biaya perbaikan $\left(\mathrm{C}_{1}\right)$ Rp68.971.634,00, dan biaya pemeliharaan $\quad\left(\mathrm{C}_{2}\right) \quad$ Rp901.587.295,00, dan parameter taksiran $\hat{b}=1,32699$ dan $\hat{a}=0,03522$ sesuai persamaan (8) diperoleh 199,32 jam. Artinya dengan risiko biaya minimum, pemeliharaan pencegahan sebaiknya dilakukan setiap mesin selesai beroperasi salama 199,32 jam operasi atau sekitar 44 kali dalam setahun.

\section{Menghitung Risiko Biaya}

Jika sistem diteliti pada waktu T, maka biaya operasi sistem per unit waktu adalah (Ebeling, 1997):

$C_{1} \int_{0}^{T} \lambda(t) d t+C_{2}$

Biaya $/$ Unit Waktu $=\frac{0}{T}$

dengan:

$\mathrm{T}=$ interval waktu(dalam jam) pemeliharaan pencegahan

Total risiko biaya pemeliharaan pencegahan biaya dengan interval waktu $\mathrm{T}=199,32$ jam, sesuai persamaan yaitu sebesar Rp13.719.929,00. Total risiko biaya permeliharaan per tahun adalah Rp602.983.033,00, sehingga berpotensi mengurangi risiko biaya cacat pada proses coating Rp290.156.967,00.

\section{Kesimpulan}

Berdasarkan hasil dan pembahasan analisis data cacat dengan menggunakan SPC maka dapat disimpulkan tahapan proses paling dominan terjadinya cacat pada proses produksi kertas dupleks yaitu proses coating. Proses coating mengakibatkan kerugian perusahaan sebesar $32,96 \%$ dari total kerugian proses produksi sebesar Rp893.140.000,00. Kontribusi cacat pada proses coating adalah $2,93 \%$, sehingga agar perusahaan dapat mengendalikan cacat mencapai kurang atau sama dengan 5\%, maka 
analisis pada proses coating perlu ditindaklanjuti. Cacat pada proses coating disebabkan oleh beberapa faktor di antaranya bahan, mesin, operator dan pengukuran dan pengujian. Mesin memberikan kontribusi utama terjadinya cacat pada proses coating yaitu $81,50 \%$. Analisis waktu antar kerusakan pada proses coating menunjukkan bahwa tingkat kerusakan pada proses coating mengikuti proses poisson non homogen model power law dengan rata-rata waktu antar kerusakan setelah mesin beroperasi selama 1 minggu adalah 4 jam. Waktu pemeliharaan pencegahan optimum mesin coating adalah setelah mesin beropersai 199,32 jam dengan risiko biaya Rp13.719.929,00. Risiko biaya ini senilai Rp602.983.033,00 setahun atau mengurangi biaya karena cacat pada proses coating Rp290.156.967,00.

\section{Daftar Pustaka}

Aksioma, D. F., Haryono, H. and Tyas, N. A. (2016) 'Penentuan Kebijakan Waktu Optimum Perbaikan Komponen Heat Exchanger (HE) Pesawat Boeing 737-800 Menggunakan Metode Power Law Process di PT. Garuda Maintenance Facility (GMF) Aero Asia', Jurnal Sains dan Seni ITS. Institut Teknologi Sepuluh Nopember, 5(1), pp. D1-D6. doi: 10.12962/J23373520. V5I1.14137.

Daulay, I. N., Nurutami, S. S. and Daniel, D. D. (2013) 'Analisis Maintenance Reliability Terhadap MTBF (Mean Time Between Failures) Facilities Pada Industri Pulp \& Paper', Jurnal Ekonomi, 21(4), pp. 1-18.

Devani, V. and Wahyuni, F. (2017) 'Pengendalian Kualitas Kertas Dengan Menggunakan Statistical Process Control di Paper Machine 3', Jurnal Ilmiah Teknik Industri, 15(2), pp. 87-93. doi: 10.23917/jiti.v15i2.1504.

Ebeling, C. E. (2004) An Introduction to Reliability and Maintainability Engineering. McGraw-Hill.

Faiq, A., Hajati, N. and Hufron, M. (2018) 'Analisis Pengendalian Kualitas Proses Produksi Jenang Apel Dengan Metode Statistical Process Control (SPC) Untuk Menurunkan Tingkat Kerusakan Produk (Studi di CV. Bagus Agriseta Mandiri Batu)', Jurnal Ilmiah Riset Manajemen, 7(5), pp. 67-78.

http://www.kemenperin.go.id (2017) RIProdusen Kertas Nomor 6 Terbesar Dunia, Berita Industri (diakses 5 November 2019).
Ihwah,A.andEkatama, B. R.(2019) 'Pengendalian Mutu Statistik Produk Akhir Paperboard (Studi Kasus PT. Surya Pamenang Kediri Jawa Timur)', Jurnal Teknologi Industri Pertanian, 29(1), pp. 19-26. doi: 10.24961/j. tek.ind.pert.2019.29.1.19.

Ilham, M. N. (2012) 'Analisis Pengendalian Kualitas Produk Dengan Menggunakan Statistical Procesing Control (SPC) Pada PT. Bosowa Media Grafika (Tribun Timur)', Jurnal Ekonomi Manajemen dan Bisnis, 8, p. 86.

Kaban, R. (2014) 'Pengendalian Kualitas Kemasan Plastik Pouch Menggunakan Statistical Procces Control (SPC) di PT Incasi Raya Padang', Jurnal Optimasi Sistem Industri, 13(1), pp. 518-547. doi: 10.25077/ josi.v13.n1.p518-547.2014.

Madanhire, I. and Mbohwa, C. (2016) 'Application of Statistical Process Control (SPC) in Manufacturing Industry in a Developing Country', in Procedia CIRP, pp. 580-583. doi: 10.1016/j.procir.2016.01.137.

Narayan, V. (2012) 'Business performance and maintenance: How are safety, quality, reliability, productivity and maintenance related?', Journal of Quality in Maintenance Engineering, 18(2), pp. 183-195. doi: 10.1108/13552511211244210.

NIST/SEMATECH (2012) e-Handbook of Statistical Methods.

Park, W. J. and Pickering, E. H. (1997) 'Statistical analysis of a power-law model for repair data', IEEE Transactions on Reliability, 46(1), pp. 27-30. doi: 10.1109/24.589922.

Render, B. and Heizer, J. (2015) Manajemen Operasi. Edisi 11. Jakarta: Salemba Empat.

Sidartawan, R. (2014) 'Analisa pengendalian proses produksi snack menggunakan metode statistical process control (SPC)', Rotor, 7(2), pp. 21-25.

Starr, A. et al. (2010) 'Maintenance today and future trends', in E-Maintenance. Springer London, pp. 5-37. doi: 10.1007/978-184996-205-6 2.

Wicaksana, D. S. (2017) 'Analisa Pengendalian Kualitas Pengantongan Semen Dengan Metode Statistical Process Control (SPC) Di PT. Semen Indonesia Tbk', Jurnal Teknik Mesin, 5(01), pp. 125-134.

Wolstenholme, L. C. (1999) Reliability Modelling: A Statistical Approach. Chapman and Hall/CRC. doi: 02/1099-1638(200009/10)16:5<452::AIDQRE371>3.0.CO;2-U. 